\title{
Peningkatan jiwa entrepreneurship bagi siswa SMK
}

\section{Eni Budiyati}

Universitas Muhammadiyah Surakarta, Indonesia, email: eb112@ums.ac.id

\section{Info Artikel}

Diajukan: 22 Jun 2021

Diterima: 25 Okt 2021

Diterbitkan: 13 Nov 2021

\section{Keywords:}

entrepreneurship; tips and

trick; business plan

Kata Kunci:

kewirausahaan; tips dan trik; rencana usaha

Lisensi:

cc-by-sa

\begin{abstract}
The productive unemployment rate in Central Java is quite high, of which $13.5 \%$ are vocational graduates. Entrepreneurship can be a solution to reduce productive unemployment. However, to run entrepreneurship requires strong interest and motivation. This community service is carried out to increase the entrepreneurial spirit of students at SMK Muhammadiyah 4 Surakarta. The implementation stages include analysis of partner problems, data collection, presentation and training, filling out post-socialization questionnaires, and evaluating the results of the implementation. Tips and tricks, challenges and obstacles, the importance of motivation in entrepreneurship are the main material presented in the presentation. In the training, students make business plans based on their individual choices. The percentage of consideration in the business field choosing is dominated by the suitability of majors in SMK (about 40\%) and the trend that is developing (20\%). While, the reasons for the suitability of hobbies, family background and others are $18 \%, 14 \%$, and $8 \%$, respectively. The students' understanding and interest in entrepreneurship increased significantly. This increase can be seen from the change in the percentage of students' plans after graduation. The number of students who wish to work in agencies or companies is around $70 \%$ (before socialization) and about 30\% (after socialization). The number of students interested in entrepreneurship increased from $15 \%$ to $68 \%$. These results show that the students' interest has shifted from "becoming an employee" to "becoming an entrepreneur".
\end{abstract}

\section{Abstrak}

Tingkat pengangguran produktif di Jawa Tengah cukup tinggi, dimana $13,5 \%$ nya adalah lulusan SMK. Kewirausahaan dapat menjadi solusi untuk mengurangi pengangguran produktif. Namun, untuk menjalankan kewirausahaan membutuhkan minat dan motivasi yang kuat. Pengabdian masyarakat ini bertujuan untuk meningkatkan jiwa entrepreneurship dari para siswa di SMK Muhammadiyah 4 Surakarta. Tahapan pelaksanaan meliputi analisis permasalahan mitra, pengumpulan data, sosialisasi dan pelatihan, pengisian kuesioner pasca sosialisasi, dan evaluasi hasil pelaksanaan. Tips and trick, tantangan dan hambatan, pentingnya motivasi dalam berwirausaha merupakan materi utama yang disampaikan dalam sosialisasi ini. Dalam pelatihan, para siswa membuat rencana usaha berdasarkan pilihan masing-masing. Persentase pertimbangan pemilihan bidang usaha tersebut didominasi oleh kesesuaian jurusan di SMK (sekitar $40 \%$ ) dan trend yang sedang berkembang (20\%). Sedangkan alasan kesesuaian hobi, background keluarga dan lain-lain masing-masing sebesar $18 \%$, 14\%, dan $8 \%$. Pemahaman dan minat para siswa terhadap wirausaha meningkat signifikan. Peningkatan tersebut dapat 
dilihat dari perubahan persentase rencana para siswa tersebut setelah lulus. Jumlah siswa yang berkeinginan untuk kerja di instansi atau perusahaan adalah sekitar $70 \%$ (sebelum sosialisas atau pelatihan) dan sekitar 30\% (setelah sosialisasi). Jumlah siswa yang berminat untuk berwirausaha meningkat dari $15 \%$ menjadi $68 \%$. Hasil-hasil tersebut menunjukkan minat para siswa mengalami pergeseran dari "menjadi karyawan" ke "menjadi wirausahawan".

\section{PENDAHULUAN}

Sekolah Menengah Kejuruan (SMK) merupakan bentuk pendidikan formal yang menyelenggarakan pendidikan kejuruan pada jenjang sekolah menengah. Berdasarkan kurikulum di Indonesia, Iulusan SMK dinyatakan sudah siap kerja, walaupun faktanya tidak semua lulusan SMK langsung bekerja. Sebagian dari lulusan tersebut melanjutkan pendidikan ke jenjang yang lebih tinggi, baik ke jenjang diploma (D3) maupun strata-1 (S1). Namun, jumlah lulusan yang melanjutkan pendidikan di perkuliahan tersebut relatif kecil. Sebagai akibatnya, sebagian besar atau mayoritas dari lulusan SMK masih berharap untuk dapat langsung kerja. Jumlah sekolah SMK yang ada di ekskaresidenan Surakarta sekitar 49 sekolah. Sekolah-sekolah tersebut menelurkan sekitar 8.000 lulusan tiap tahunnya (BPS Surakarta, 2021). Jumlah yang relatif banyak, dan apabila diakumulasi dalam 5 atau 10 tahun ke depan dapat dibayangkan berapa banyak kebutuhan lapangan pekerjaan bagi lulusanlulusan tersebut. Banyak perusahaan dari luar daerah, seperti Semarang, Jakarta, Surabaya yang bekerjasama dengan sekolah-sekolah SMK di Surakarta untuk merekrut lulusan sekolah tersebut. Namun, jumlah tersebut masih belum berimbang. Berdasarkan data BPS, pada tahun 2020 jumlah pengangguran di Jawa Tengah didominasi oleh lulusan SMK, yaitu sekitar $13,5 \%$ (BPS Surakarta, 2021). Akumulasi jumlah lulusan SMK yang membutuhkan pekerjaan terus bertambah dan tidak diikuti oleh penambahan jumlah lapangan pekerjaan yang tersedia. Bahkan tidak banyak perusahaan yang notabene cukup besar harus gulung tikar. Sebagai akibatnya, tingkat kompetisi atau persaingan dalam mencari pekerjaan meningkat. Bahkan, dalam jangka panjang hal ini juga dapat memicu kenaikan tingkat pengangguran dari waktu ke waktu.

Kondisi tersebut juga akan memberi dampak bagi siswa SMK Muhammadiyah 4 Surakarta. Untuk mengurangi tingkat pengangguran produktif tersebut, harus dilakukan langkah preventif yang dapat menjadi solusi. Solusi yang cukup realistis adalah dengan mempersiapkan para siswa SMK (calon lulusan) untuk menjadi usahawan (entrepreneur). Berdasarkan hasil analisis permasalahan mitra, pemahaman dan keahlian dalam berwirausaha dari siswa masih relative rendah. Hal ini yang memotivasi pengabdi untuk menawarkan solusi. Salah satu alternatif yang dapat dilakukan adalah dengan memberikan bekal kewirausahaan kepada para calon lulusan tersebut. Dengan kemampuan entrepreneurship, calon lulusan tidak hanya fokus untuk mencari pekerjaan (bergantung pada ketersediaan lapangan pekerjaan), tetapi dapat membuat usaha sendiri (wirausaha). Harapan berikutnya, apabila usaha yang mereka rintis dapat berkembang dengan baik, akan memungkinkan bagi 
mereka untuk menciptakan lapangan pekerjaan bagi orang lain (Helmi, 2009). Jiwa kewirausahaan (entrepreneurship) merupakan hal yang penting untuk dibekalkan kepada para siswa SMK (Salirawati, 2012). Jiwa kewirausahaan meliputi komitmen, keseriusan dalam pengambilan keputusan, dan konsistensi (Zahra et al., 2019). Di samping itu, self-efficacy mempunyai peran penting dalam meningkatkan daya tarik dan mendorong minat calon lulusan untuk memulai wirausaha. Secara umum, self-efficacy calon lulusan mempunyai korelasi berbanding lurus terhadap minat mereka dalam berwirausaha (Wijaya et al., 2015). Berdasarkan studi dan evaluasi yang dilakukan, penanaman jiwa wirausaha mempunyai efek yang lebih efektif apabila dilakukan dari dini. Sebagai contoh pembekalan entrepreneurship skill yang dilakukan pada usia dini memberikan kontribusi positif terhadap motivasi dan minat anak-anak untuk berwirausaha (Ndeot, 2018).

Faktor yang berpengaruh terhadap minat dan motivasi siswa dalam berwirausaha dapat dikategorikan ke dalam faktor internal dan eksternal. Faktor internal merupakan faktor yang berasal dari individu yang mendorong seseorang untuk berwirausaha. Beberapa faktor internal antara lain: need achievement, kreatifitas, risk taking, inovasi, dan lain-lain (Adhimursandi, 2016). Sedangkan faktor eksternal merupakan faktor yang berasal dari luar individu tersebut. Faktor eksternal ini mempunyai peran yang penting dalam memperkuat minat dan motivasi siswa untuk memiliki jiwa kewirausahaan. Faktor eksternal dalam berwirausaha adalah lingkungan sosio ekonomi dan lingkungan keluarga (Nagel \& Suhartatik, 2018). Motivasi kewirausahaan harus mempertimbangkan bagaimana kata-kata dan tindakan mereka mempengaruhi kelancaran usaha mereka. Tujuan, harapan, aspirasi, values, dan self-esteem merupakan beberapa hal terkait motivasi tersebut (Obschonka et al., 2012). Menjadi pengusaha atau wiraswasta harus berani memulai, mengatur, mengelola, dan memikul tanggung jawab terhadap bisnis. Di sisi lain, kegagalan usaha merupakan faktor penghambat terbesar dalam berwirausaha (Irawati, 2017). Oleh karena itu, dalam menjalankan wirausaha terdapat tantangan untuk menjadi pribadi yang lebih ulet dan pantang menyerah (Segal et al., 2005). Karena jiwa mandiri, pantang menyerah, dan pandai melihat peluang merupakan kunci sukses seorang entrepreneur (Jumarniati et al., 2020). Perencanaan yang baik dalam pengendalian yang sistematis dalam memulai suatu usaha juga memiliki pengaruh yang besar pada proses menjalankan usaha tersebut. Kedua hal tersebut dapat membantu dalam mengkoordinir dan mengatur sistem produksi, pembiayaan, maupun pemasarannya (Jumarniati et al., 2019).

Masalah yang dihadapi para siswa SMK (termasuk SMK Muhammadiyah 4 Surakarta) adalah jumlah lapangan pekerjaan yang tidak sebanding dengan jumlah lulusan yang ada. Wirausaha dapat salah satu alternatif untuk menambah lapangan pekerjaan. Namun pemahaman dan kemampuan siswa dalam berwirausaha masih kurang. Oleh karena itu, pengabdian masyarakat ini bertujuan untuk memberikan sosialisasi dan pelatihan berwirausaha bagi siswa SMK Muhammadiyah 4 Surakarta. Selain itu, kegiatan ini juga bermaksud untuk memberi solusi permasalahan mitra 
dengan menanamkan jiwa kewirausahaan kepada mitra (para siswa SMK) sebagai bekal ke depannya.

\section{METODE PELAKSANAAN}

Kegiatan pengabdian masyarakat dilaksanakan dalam beberapa tahapan, yaitu: analisis permasalahan mitra, pengumpulan data (kuesioner), sosialisasi dan pelatihan, pengisian kuesioner pasca sosialisasi, dan evaluasi hasil pelaksanaan. Masing-masing tahapan akan dijabarkan pada uraian selanjutnya.

Analisis permasalahan mitra dilakukan dengan komunikasi dan bekerjasama dengan salah satu Guru kelas di SMK Muhammadiyah 4 Surakarta. Diskusi lebih ditekankan pada profil dan tracer study mitra dalam rangka mengatasi masalah yang dihadapi mitra dan kemungkinan solusinya. Selanjutnya, pengumpulan data dilakukan dengan menggunakan sistem kuesioner kepada 50 responden. Koresponden yang dipilih adalah siswa kelas 3 SMK Muhammadiyah 4 Surakarta. Hasil analisis dan kuesioner digunakan sebagai acuan untuk membuat solusi penyelesaiannya.

Berdasarkan berbagai pertimbangan (efektivitas dan efisiensi), solusi yang tepat untuk menyelesaikan permasalahan mitra adalah dengan membekali mereka keahlian berwirausaha. Oleh karena itu, dalam pelaksanaannya dilakukan sosialisasi dan pelatihan entrepreneurship. Sosialisasi ini dilakukan dengan presentasi materi dan sesi tanya jawab. Materi yang disampaikan meliputi tips and trick berwirausaha, tantangan dan hambatan, pentingnya motivasi dalam berwirausaha. Dalam kegiatan ini juga disampaikan beberapa contoh wirausahawan yang harus berjuang keras untuk mencapai titik keberhasilan mereka. Hal ini dimaksudkan untuk memberikan gambaran secara nyata, bahwa para usahawan besar tidak langsung berhasil saat memulai usaha. Sebagian besar dari mereka mengalami kerugian yang tidak kecil, bahkan beberapa usahawan ini mengganti jenis usaha setelah berulang kali menjalankan usaha yang sama mengalami kegagalan. Tanya jawab dimaksudkan untuk memberi ruang bagi para siswa untuk bertanya tentang hal-hal yang lebih detail. Kegiatan ini diselenggarakan di salah satu kelas di SMK Muhammadiyah 4 Surakarta.

Motivasi para siswa yang tinggi dan dukungan sekolah terhadap kegiatan ini menjadi kunci kelancaran proses sosialisasi. Bekal pengetahuan dan pemahaman para siswa tentang kewirausahaan digunakan untuk melatih mereka melakukan uji coba atau praktek berwirausaha. Para siswa diberi kebebasan untuk memilih dan merancang jenis usaha yang diinginkan. Poin utamanya adalah mereka harus menjelaskan bagaimana pemasarannya, keunggulan produk mereka yang mempunyai nilai kompetitif dengan produk sejenis yang sudah ada, dan perhitungan profit/keuntungan. Pada prinsipnya, para siswa dilatih untuk membuat plan usaha yang mereka pilih, mulai dari bahan sampai pemasarannya.

Langkah selanjutnya adalah evaluasi pelaksanaan pengabdian masyarakat. Evaluasi dilakukan dengan diskusi dan pengisian kuesioner. 
Dalam diskusi ini, para siswa juga diperkenankan untuk sharing maupun bertanya lebih lanjut terkait planning mereka. Sedangkan poin-poin pertanyaan kuesioner yang digunakan sama dengan kuesioner yang diberikan sebelum pelaksanaan sosialisasi dan pelatihan.

\section{HASIL DAN PEMBAHASAN}

Pengabdian masyarakat ini diawali dengan analisis permasalahan dan pengumpulan data penunjang. Berdasarkan diskusi dengan dua guru di SMK Muhammadiyah 4 Surakarta, diperoleh kesimpulan bahwa pelaksanaan kegiatan belajar mengajar (KBM) relatif berjalan dengan baik. Bahkan, dari sisi prestasi, para siswa di sekolah tersebut mempunyai kemampuan akademik maupun non akademik yang baik dan dapat bersaing dengan siswa-siswa di sekolah lain. Namun, mengingat jumlah lulusan yang tidak sebanding dengan lapangan pekerjaan yang tersedia, maka diharapkan minat calon lulusan sekolah tersebut mulai bergeser untuk berwirausaha. Untuk mengetahui minat pekerjaan para calon lulusan SMK (siswa/siswi SMK kelas 3), dilakukan pengumpulan data menggunakan kuesioner. Dari hasil kuesioner tersebut, mayoritas para siswa masih bertumpu pada keinginannya untuk bekerja ke instansi, perusahaan atau pihak lain (menjadi karyawan). Hanya sekitar $15 \%$, yang menyatakan siap untuk membuka usaha sendiri. Dan yang terpenting, hampir $70 \%$ menyatakan belum tahu apa yang akan dilakukan apabila mereka tidak mendapatkan pekerjaan di instansi, perusahaan, atau pihak yang lain tersebut.

Berdasarkan data tersebut, dilakukan sosialisasi dan pelatihan entrepreneurship. Kegiatan ini mendapat tanggapan yang positif dari para siswa maupun guru di SMK Muhammadiyah 4 Surakarta. Dalam kegiatan tersebut para siswa dan guru (staf pengajar) sangat antusias untuk mengikuti setiap tahapan. Pada paparan materi, mereka lebih tertarik untuk diskusi terkait bagaimana memulai suatu usaha dan apa yang harus dilakukan agar tidak mengalami kerugian dalam merintis usaha. Oleh karena itu, materi tips and trick cukup memberikan semangat baru bagi para peserta. Memang dalam berwirausaha harus siap untuk gagal, namun kejadian itu dapat diminimalisasi dengan persiapan dan planning yang matang. Foto kegiatan sosialisasi dan presentasi materi disajikan dalam Gambar 1 dan 2.

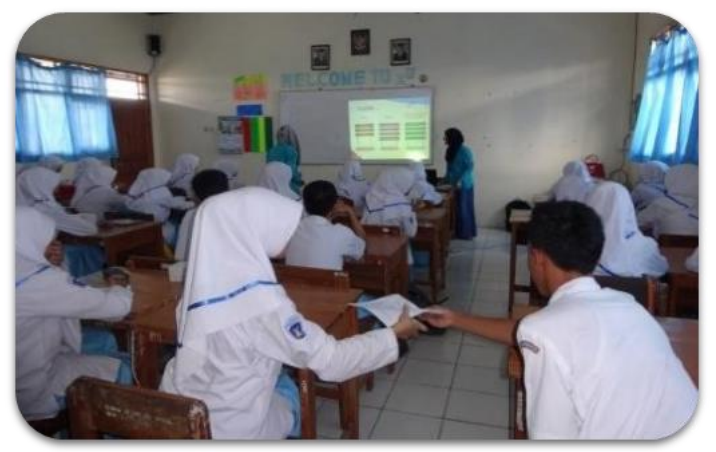

Gambar 1. Sosialisasi dan presentasi materi tentang enterpreneurship 


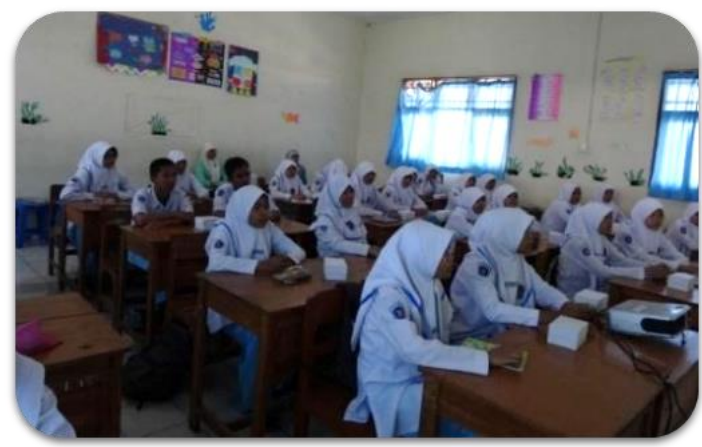

Gambar 2. Motivasi peserta dalam mengikuti sosialisasi

Pelatihan dilakukan sebagai tindak lanjut dari presentasi atau pemaparan materi. Pada kegiatan ini para siswa diberi tugas untuk membuat rancangan rencana usaha. Rancangan tersebut berisi jenis usaha, pemasaran (baik tempat maupun metode), perhitungan profit secara sederhana. Sebagian besar sudah mengaplikasikan tips and trick yang disampaikan pada pemaparan materi. Hal itu ditunjukkan dalam mempersiapkan model usaha yang akan dijalankan, berani berpikir "out of the box", dan terlihat cukup jelas dalam melihat peluang dan menentukan target pasar. Bagian-bagian tersebut mereka tampilkan dalam plan, termasuk perkiraan profit maupun tempat usahanya. Hanya sebagian kecil dari mereka $(<10 \%)$ yang masih belum bisa menuliskan dan menjelaskan planning usaha secara jelas dan runtut. Namun, secara keseluruhan dapat dikatakan bahwa sosialisasi ini berhasil.

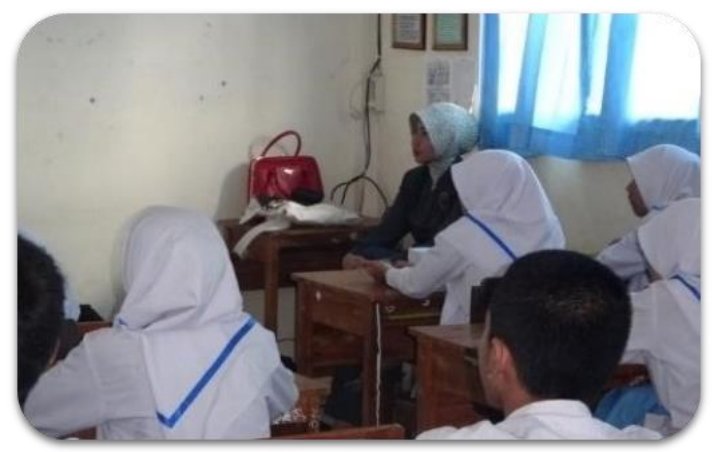

Gambar 3. Pelatihan pembuatan rencana usaha

Dalam pelatihan ini, para siswa juga diperkenankan untuk bertanya maupun diskusi. Mereka diberi ruang untuk mengeluarkan ide-ide unik yang mereka miliki. Sebagai hasilnya, banyak kreativitas positif mereka yang sangat potensial untuk dilanjutkan dalam bentuk nyata. Beberapa kreasi tersebut antara lain: packing yang digunakan untuk membungkus produk, sistem pemasaran (promo, diskon, dan lain-lain), dan bentuk produk yang unik. Kreativitas ini dilatarbelakangi oleh perilaku konsumen yang cenderung menyukai sesuai yang berbeda dari biasanya. Ditambah lagi, penggunaan 
media sosial yang dapat membantu sarana promosi maupun pemasarannya. Pada kegiatan ini, guru pendamping juga ikut aktif mendampingi pelaksanaan kegiatan maupun diskusi. Hal ini sangat menunjang untuk mencapai keberhasilan kegiatan.

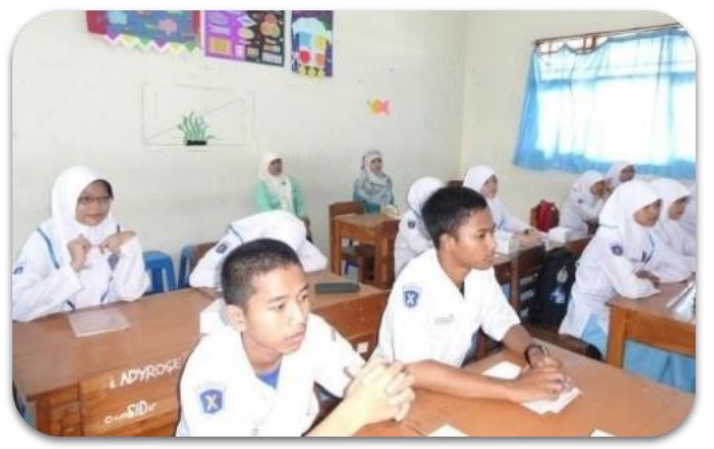

Gambar 4. Tanya jawab yang kondusif dan pendampingan dari perwakilan guru

Pada pelatihan membuat rencana usaha, para siswa memilih bidang usaha berdasarkan pertimbangan yang berbeda-beda. Pertimbangan tersebut antara lain, berdasarkan tren, hobi, background keluarga, jurusan yang mereka ambil di SMK ini, dan lain-lain. Hasil persentase pertimbangan pemilihan jenis usaha yang diambil dapat dilihat pada Gambar 5. Dari gambar tersebut terlihat bahwa pilihan usaha yang mereka rencanakan masih didominasi oleh kesesuaian dengan jurusan di SMK, yaitu sekitar $40 \%$. Hal ini wajar, mengingat alasan utama para siswa ini memilih jurusan di SMK adalah ketertarikan mereka untuk bekerja di bidang tersebut. Posisi kedua adalah jenis usaha yang sedang trend. Para siswa melihat peluang pasar yang lebih besar untuk menjual produk kuliner yang sedang digemari, seperti katsu, bobba, Korean food, dan sebagainya. Mereka juga tertarik untuk menjual produk melalui sistem online. Penjualan online tidak harus menyiapkan tempat atau toko. Di samping itu, dalam penjualan tersebut, sistem pemasaran dapat relatif lebih mudah dan luas mengingat semakin berkembangnya media sosial pada saat ini. Tentu hal ini dapat dijadikan sebagai peluang bagi para siswa.

Hobi atau kegemaran tidak hanya dimanfaatkan untuk refreshing atau kesenangan saja, melainkan dapat dijadikan sebagai usaha/bisnis. Hal ini lah yang disampaikan beberapa siswa. Mereka lebih memilih usaha sesuai dengan hobi yang mereka tekuni. Sebagai contoh olahraga dan bertaman. Mereka merasa akan lebih nyaman apabila memiliki usaha dalam bidang tersebut (menjual perlengkapan olahraga dan menjual berbagai jenis tanaman, media tanam, pupuk dan pot). Persentase siswa yang memilih usaha sesuai hobi adalah sekitar $18 \%$. Sedangkan background keluarga juga memiliki pengaruh yang cukup besar, terutama bagi siswa yang orangtuanya merupakan wirausahawan. Sekitar $14 \%$ dari mereka memilih bidang usaha sesuai dengan usaha yang sudah dikelola oleh orang tua mereka. Alasannya adalah mereka sudah memiliki pengalaman dan melanjutkan usaha orang tua. Di samping itu, 
market area yang relatif sudah stabil, memberi kesempatan mereka untuk lebih fokus dalam pengembangan usahanya bukan mencari pasar/konsumen. Namun, sebagian berkeinginan untuk menjadi wirausahawan dengan bidang usaha yang berbeda dari bidang usaha orang tua mereka. Artinya, mereka merasa bahwa contoh konkrit dari orang tua mereka dapat menginspirasi mereka untuk menjalankan usaha sendiri. Pemilihan bidang usaha yang berbeda disebabkan karena memang mereka kurang tertarik dengan bidang usaha yang ditekuni oleh orang tua mereka.

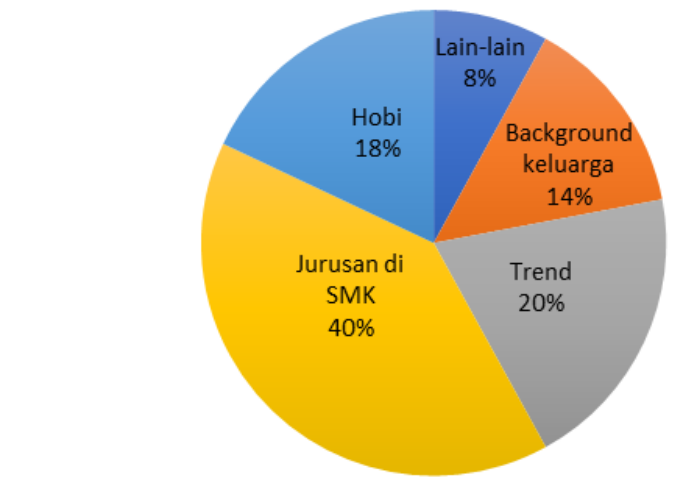

Gambar 5. Diagram persentase pertimbangan pemilihan jenis usaha

Berdasarkan diskusi akhir, diperoleh hasil bahwa pemahaman maupun minat para siswa untuk berwirausaha mengalami peningkatan. Para siswa sudah mampu membuat rencana kerja yang sistematis, dan beberapa diantaranya sudah mencoba berwirausaha secara langsung. Sebagian besar siswa yang awalnya setelah lulus berkeinginan untuk mencari pekerjaan bergeser untuk mencoba membuka usaha sendiri, meskipun dimulai dari nol. Hasil selengkapnya disajikan pada Gambar 6. Dari gambar terlihat bahwa minat menjadi karyawan mengalami penurunan tajam. Sebelum sosialisasi, sekitar $70 \%$ dari siswa berkeinginan untuk kerja di instansi atau perusahaan. Jumlah tersebut berubah menjadi sekitar $30 \%$, setelah adanya kegiatan pengabdian masyarakat ini. Sedangkan jumlah siswa yang berminat untuk membuka usaha sendiri mengalami kenaikan dari $15 \%$ menjadi $68 \%$. Dan yang terpenting, jumlah siswa yang belum memiliki rencana setelah mereka lulus tinggal sedikit, yaitu sekitar $2 \%$. Hal ini menunjukkan kegiatan ini mempunyai efek positif terhadap motivasi dan minat para siswa untuk mempersiapkan masa depan mereka. 


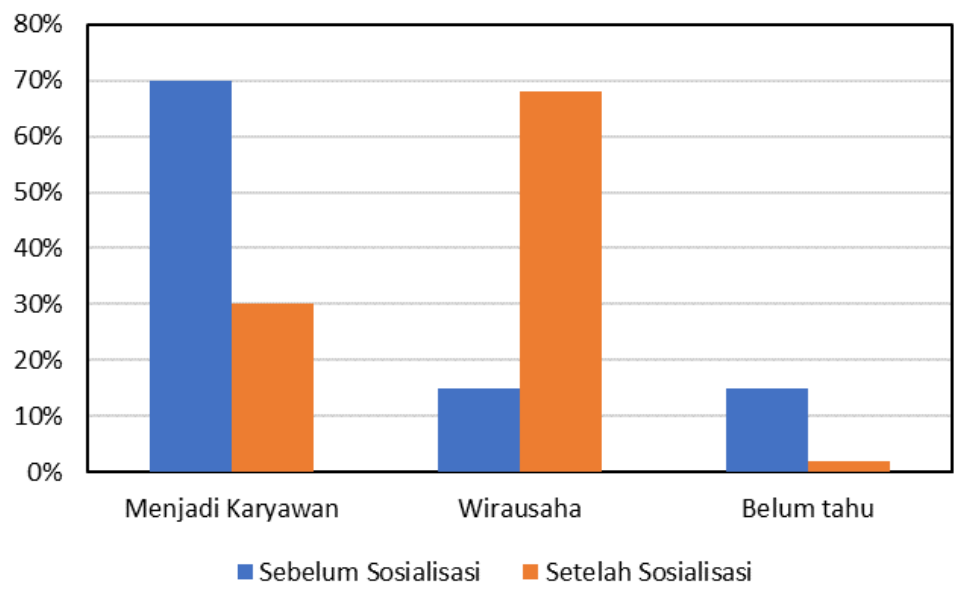

Gambar 6. Perbandingan hasil kuesioner sebelum dan setelah sosialisasi

Tahapan selanjutnya adalah evaluasi hasil pengabdian masyarakat (PM). Berdasarkan tracer yang dilakukan terhadap peserta kegiatan PM, diperoleh jumlah lulusan yang sudah berani berwirausaha (baik melanjutkan usaha orang tua maupun merintis sendiri) adalah sekitar 35\%. Jumlah ini belum sesuai dengan hasil kuesioner yang dilakukan (68\%). Secara teoritis, sekitar 34 siswa (dari 50 responden) yang sudah menjalankan usaha sendiri. Penyebab utamanya adalah lulusan tersebut mempunyai kendala pada ketersediaan modal untuk memulai usahanya. Secara keseluruhan, pengabdian masyarakat ini cukup berhasil dalam memberikan ide dan motivasi kepada para siswa untuk berwirausaha. Hal tersebut merupakan hal yang sangat penting dalam melaksanakan wirausaha.

\section{KESIMPULAN}

Pengabdian masyarakat ini dilaksanakan di SMK Muhammadiyah 4 Surakarta. Tujuan utamanya adalah ikut memecahkan masalah yang dihadapi mitra, yaitu dengan sosialisasi dan pelatihan entrepreneurship (termasuk membuat rencana usaha). Hal tersebut dilakukan untuk membekali para siswa SMK (sebagai mitra) dengan keahlian dan jiwa berwirausaha. Tahapan yang digunakan dalam pelaksanaan pengabdian masyarakat ini antara lain: analisis permasalahan mitra, pengumpulan data dengan kuesioner, pemaparan materi dan tugas kewirausahaan, pengisian kuesioner setelah sosialisasi, dan evaluasi hasil pelaksanaan. Hasil PM menunjukkan bahwa bidang usaha yang mereka pilih didasarkan pada beberapa alasan, antara lain: trend, hobi, background keluarga, jurusan yang mereka ambil di SMK ini, dan lain-lain.

Persentase pertimbangan pemilihan bidang usaha tersebut didominasi oleh jurusan SMK (sekitar 40\%), diikuti oleh trend (20\%), hobi $(18 \%)$, background keluarga (14\%) dan lain-lain (8\%). Di samping itu, pemahaman dan minat para siswa terhadap wirausaha mengalami peningkatan yang signifikan. Hal ini ditunjukkan oleh perubahan persentase rencana para siswa tersebut setelah lulus. Sebelum sosialisasi, sekitar $70 \%$ dari siswa berkeinginan untuk 
kerja di instansi atau perusahaan. Jumlah tersebut berubah menjadi sekitar $30 \%$, setelah adanya kegiatan pengabdian masyarakat ini. Sedangkan jumlah siswa yang berminat untuk berwirausaha meningkat dari $15 \%$ menjadi $68 \%$. Berdasarkan hasil evaluasi pelaksanaan PM, sekitar 35\% yang benar-benar sudah berwirausaha, baik dengan merintis usaha itu sendiri atau melanjutkan usaha orang tua. Berdasarkan hasil secara keseluruhan, kegiatan ini mempunyai dampak dan positif dan dapat direkomendasikan sebagai kegiatan rutin di SMK tersebut.

\section{DAFTAR RUJUKAN}

Adhimursandi, D. (2016). Faktor-Faktor yang Mempengaruhi Niat Kewirausahaan. Jurnal Ekonomi Dan Manajemen, 13(2), 193-210. https://doi.org/10.29264/jkin.v13i2.63

BPS Surakarta. (2021). Badan Pusat Statistik Kota Surakarta (Statistics of Surakarta Municipality).

Helmi, A. F. (2009). Kewirausahaan di Perguruan Tinggi dalam Perspektif Psikologi. Buletin Psikologi, 17(2), 57-65. https://doi.org/10.22146/bpsi.11483

Irawati, R. (2017). Pengambilan Keputusan Usaha Mandiri Mahasiswa Ditinjau dari Faktor Internal dan Eksternal. Jurnal JIBEKA, 11(1), 58-69. https://doi.org/10.32812/jibeka.v11i2.61

Jumarniati, Baharuddin, M. R., \& Hisani, W. (2020). Peluang Wirausaha Mandiri melalui Diversifikasi Olahan Kelapa. To Maega: Jurnal Pengabdian Masyarakat, 3(2), 83-91. https://doi.org/10.35914/tomaega.v3i2.381

Jumarniati, Saruman, S. H., \& Baharuddin, M. R. (2019). Perempuan Penjual Pecel Lamasi , Kecamatan Lamasi , Kab . Luwu. CARADDE: Jurnal Pengabdian Kepada Masyarakat, 1(2), 105-110. https://doi.org/10.31960/caradde.v1i2.68

Nagel, P. J. F., \& Suhartatik, A. (2018). Faktor Internal dan Eksternal Minat Berwirausaha dan Keberhasilan Usaha pada UMKM di Surabaya. Jurnal Keuangan Dan Perbankan, 15(1), 53-63. http://journal.ibs.ac.id/index.php/jkp/article/view/164

Ndeot, F. (2018). Menanamkan Jiwa Kewirausahaan Sejak Usia Dini di Era MEA. PERNIK Jurnal Pendidikan Anak Usia Dini, 1(1), 1-9. https://doi.org/10.31851/pernik.v1i01.2621

Obschonka, M., Silbereisen, R. K., \& Jena, F. (2012). Thematic Issue: Guest Editorial Entrepreneurship from a Developmental Science Perspective. International Journal of Developmental Science, 6, 107-115. https://doi.org/10.3233/DEV-2012-12105

Salirawati, D. (2012). Self-confidence, curiosity, and entrepreneurship: three important characters for the students. Jurnal Pendidikan Karakter, II(2), 213-224.

Segal, G., Borgia, D., \& Schoenfeld, J. (2005). The motivation to become an entrepreneur. International Journal of Entrepreneurial Behaviour \& Research, 11(1), 42-57. https://doi.org/10.1108/13552550510580834

Wijaya, T., Nurhadi, \& Kuncoro, A. M. (2015). Intensi Berwirausaha Mahasiswa: 
Perspektif Pengambilan Risiko. Jurnal Siasat Bisnis, 19(2), 109-123. https://doi.org/10.20885/jsb.vol19.iss2.art2

Zahra, A. A., Husna, A. N., Liana, A., \& Haq, A. (2019). Dinamika Pengambilan Keputusan dan Perkembangan Jiwa Wirausaha pada Mahasiswa. PSYMPATHIC: Jurnal IImiah Psikologi, 6(2015), 111-130. https://doi.org/10.15575/psy.v6i1.3464 